\title{
READING DIGITAL TEXT AS A NEW LITERACY IN ELT: TEACHERS' PERCEPTION \& PRACTICES
}

\author{
Anita Fatimatul Laeli \\ Language and Literature Education Program, Post Graduate, Universitas Negeri Surabaya, East Java, Indonesia English \\ Education Department, Universitas Muhammadiyah Jember, East Java, Indonesia \\ anitafatimatul@unmuhjember.ac.id \\ Slamet Setiawan \\ Language and Literature Education Program, Post Graduate, Universitas Negeri Surabaya, East Java, Indonesia \\ slametsetiawan@unesa.ac.id \\ Syafi'ul Anam \\ Language and Literature Education Program, Post Graduate, Universitas Negeri Surabaya, East Java, Indonesia \\ syafiul.anam@unesa.ac.id
}

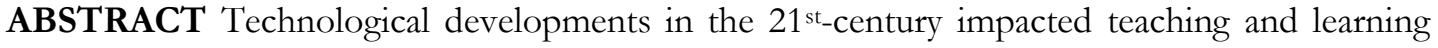
English. One of the impacts of this technological development is reading activities and competencies, reading experienced a phase of change from printed text to digital text. The change from Printed text to digital text requires new literacies, such as locating information and synthesizing online information. This case study aimed at investigating teachers' perceptions and practices of reading digital texts in ELT. About twenty-three ELT teachers, both in junior and senior high schools around East Java, were involved in this study. An open-ended questionnaire was distributed to portray ELT teachers' attitudes, knowledge, and practices in reading digital text. The study revealed that all teachers have a positive attitude toward the practice of reading digital text. However, most teachers have misconceptions about knowledge and practice in implementing reading digital text activities. Surprisingly, all teachers in this study claimed that they never received a particular workshop to read digital text activities for English class. Hopefully, this study's result could contribute to the ELT curriculum in responding to the need to facilitate the new literacy in (online) reading and teacher professional development to develop teachers' reading digital text competencies. However, teachers as facilitators in classroom learning activities must recognize new literacy in online reading (especially reading digital text) to help students achieve reading competence in today's digital-based information era.
\end{abstract}

Keywords: digital text; new reading literacy; teachers' perception

\section{A. INTRODUCTION}

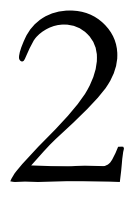

$1^{\text {st }}$ - Century learning is the implication of human civilization development based on the development of science and technology. The development of science and technology impacted all human needs, including education. This fact leads to a notable transition in the teaching and learning process. The transformation of teaching and learning (including in Indonesia) is noticed guidelines in the preparation of learning devices which in designing classroom activities, the teacher must integrate ICT (TPACK) into the learning process. Online teaching is one of the implications of students' changing needs with technology development (Conrad \& Pedro, 2009). It is undeniable that the use of the internet has become a necessity in daily life and education, and we can see that information can be easily obtained through the internet without restrictions. As a result, teachers are required to 
have digital literacy to help students meet their needs. Digital literacy is a skill related to using technology to identify, assess, formulate, conceive, and share the information to solve the issue in technological settings (Harris, 2015). Furthermore, related to explore and distribute information through the internet, digital literacy can define as the ability to encounter valid information and behave wisely and safely in online activities (Murtafi'ah \& Putro, 2019). Indonesian teachers claimed that language learning should incorporate a range of technologies to develop students' language skills (Pratolo \& Solikhati, 2020). So, teachers and program administrators need to incorporate opportunities to grow digital literature into lessons, Curriculum, and services (Harris, 2015).

Recently, researchers have shown an increased interest in investigating digital literacy within education. A literature-based paper conducted by Murtafi'ah \& Putro (2019) proposed approaches and models to promote digital teaching literacy in English classes for senior high school. Murtafi'ah \& Putro (2019) offer dispersion and infusion as suitable approaches for the model of teaching digital literacy in English class. The first model proposed is building the students' recognition to separate actual/good and hoax news; this activity is integrated to teach news item text. The second model is building the students' recognition to behave safely to make use of internet/online activities, it is integrated in teaching procedure text or posting which ask the students to give tips in using the internet. However, this paper has not investigated how this model can improve students' English skills, such as listening, reading, speaking, and writing.

Further, studies on teachers' beliefs and attitudes on digital literacy in English class have attracted several researchers; Laksani (2019) conducted a descriptive study that focuses on teachers' belief in integrating digital literacy in the teaching process. The planned behavior theory was used to investigate teachers' beliefs that cover behavior, normative, and control belief. This study reveals that teacher behavior belief shows a positive commitment to accommodate digital literacy in the class, since digital literacy provides many advantages for both teacher and students in the class activities. Further, teachers' norms were strongly affected by parents, school administrators, and students' perceptions. Moreover, the availability of access to technology has been described as among the most critical aspects of incorporating digital literacy into classrooms (teacher's control belief). Another similar study concludes that some factors could affect a teacher's attitude toward integrating digital literacy in the class. Pratolo \& Solikhati (2020) conducted a descriptive study investigating teachers' attitudes in digital literary practice, challenges, and strategies used by the teacher to cope with digital literacy problems in the teaching and learning process. Two English teachers were 
involved in the study, in which both the English teachers are categorized as the millennial generation with sufficient technical skill to be digitally literate. This previous study reveals that teachers have a positive attitude toward integrating digital literacy in English class. the challenge faced by the teachers is mostly from the external factor, including the school's facilities and funds to provide technology and the students' readiness in learning with technology. Teachers need mastery of digital literacy to help students have the ability to filter and manage the information they get from the use of technology. The ability to filter and manage information is a learning component provided in this $21^{\text {st }}$-century learning, as Ozden (2018) explains digital literacy as the ability to access information in electronic form. Reading competence is needed to be able to analyze and producing information from digital devices.

The specific implication from the technological development phase is digital-based information. The impact of digital-based information that occurs ELT is a phase of change from printed text to digital text. So, the importance of initiating students with reading the digital text as a new literacy for the digital environment cannot be avoided. The speed and breadth of information in the digital world (the internet) requires students to have digital text reading skills. Responding to this issue, there has been an increasing interest in reading digital text, an investigation on how English as second language learners practice web text, how students navigate the link on the internet was conducted by Gilbert, (2017). He examined how English students (ESL context) comprehend and evaluate reading through digital literacy skills. The study suggests that language learners engage in typically altered reading strategies and practices when reading web text; further, the study indicates the need for digital literacy skills to be trained in connection with the development of traditional literacy skills in the target language. Several studies have revealed that online reading strategies involve selecting, navigating, evaluating, and locating the information in an online source ((Park \& Kim, 2017; \& Cho \& Afflerbach, 2017).

However, there have been few discussions about English teachers' knowledge, attitudes, and practices toward reading digital text. It is due to English teachers must have a comprehensive knowledge of what reading digital text is and how to implement it in the classroom, which is integrated with several topics that have been listed in the Curriculum. So that teachers can engage the students to work with digital text. This paper attempts to investigate English teachers' perceptions and practices toward reading digital text. This study's primary purpose is to portray the teachers' attitude, knowledge, and practices of reading digital text in the class. In particular, this study will examine three research questions: a) how are English teachers' attitude toward reading digital text for students? b) how do English teachers 
define reading digital text; and c) how do English teachers implement reading digital text practices in the classroom? Hopefully, this study will make a significant contribution to English learning and teaching, especially in reading competencies that are adapted to the development of $21^{\text {st }}$-century learning.

\section{B. REVIEW OF LITERATURE}

\section{$21^{\text {st }}$ - Century Students' Characteristics and Competencies}

Today, students who are in the $21^{\text {st }}$-century are called digital natives. A Digital native is a person who utilizes technology/digital media in their daily activities (Prensky, 2001). Regarding education, Trilling \& Fadel (2009) identifies the skills that must be possessed by the $21^{\text {st }}$-century generation, among other things, skills in learning and innovating, and students are asked to be able to think critically in the learning process and in solving a problem. One of the implications of this demand is the student-centered learning approach that encourages students to be responsible for controlling their learning, which leads to an increase in their EFL skills (Wiraningsih \& Santosa, 2020). The ability to think creatively and innovatively is also a skill that must be mastered and build for $21^{\text {st }}$-century students. They are already in the era of highly creative digital-based industries that require creative and innovative products, another must-have for students of the $21^{\text {st }}$ century is digital literacy expertise, both in operating new media and in ICT literacy. These skills absolutely must be possessed by $21^{\text {st }}$ century students because they were born and grow during the rapid development of technology. Thus, $21^{\text {st }}$-century students are not only expected to be able to use digital media technologies, but they can use it in their learning activities. Finally, $21^{\text {st }}$-century students must possess social skills in interacting between cultures or between nations. The digital world provides opportunities for them to interact with anyone from all parts of the world. Not only communicating, but they can also share knowledge and expertise according to their talents and interests. The integration of technology in learning has become a necessity in $21^{\text {st }}$-century learning since it could be one factor to help the students be autonomous learners (Wiraningsih \& Santosa, 2020).

Based on some of the discussion above, new classroom activities are required to help today's learners, demonstrating diverse learning characteristics as a caused by exposure to and familiarity with technology (Seok \& DaCosta, 2016). Hence, teachers need to provide students with the new literacy, mainly digital text in reading online, by providing students sources from the internet and equipping them with competence/activities in utilizing these digital resources. Although in reality, sometimes students are more skilled at operating specific applications than their teachers. In this situation, the teacher's role changes from being a creator to a 
facilitator of the learning process. Those who already have more digital literacy can share their experiences with other friends in the class, and do not rule out the teacher will also learn together with the students in a class (Harris, 2015). Therefore, this study was conducted to ensure that teachers have the appropriate framework in facilitating students to accommodate their needs as $21^{\text {st }}$ - century students, that is, reading digital texts.

\section{New Literacy in Reading}

The use of technologies such as mobiles, computers, and the internet in today's life leads to an enormous change in English teaching and learning. The most key system to bring current technology is the internet, which enforced new writing competencies, reading, and communicating adequately (Leu et al., 2011). The internet provides users to read texts within a new environment called digital text (Coiro \& Dobler, 2007). Reading digital text refers to reading online in the internet sources that allow readers to read the hypertext information, containing multiple webs, links, and nodes (Cho \& Afflerbach, 2017). Besides, texts in the digital environment have various formats (paragraphs, graphs, pictures, and charts) (Seok \& DaCosta, 2016). In other words, the use of technology-particularly the use of the internetenlarges the tradition of reading in a printed text to read digital text.

Concerning reading digital text, three main theoretical perspectives are associated; literacy, technology, and learning (Coiro \& Dobler, 2007). Reading is viewed as a constructive and making-meaning process; readers interact with the text to construct meaning actively. In this process, readers mostly used cognitive processing strategy by asking questions, connections, drawing, and an inference. Readers tend to interpret and evaluate particular texts to answer the task. The perspective concerning digital text is mastering the new literacy that developed along with the development of technology. For this new literacy, readers are required to read the information provided in internet sources. Adequate reading comprehension should include new skills and strategies to read and learn from information on the internet. The last theoretical perspective is learning; internet readers learn to construct meaning from the text and construct meaning through the purposeful and flexible choice of related icons, interactive diagrams, and hyperlinks. In the digital text, reading activities requires the ability to use computers or the internet and locate, evaluate, communicate, synthesize information, and navigate hyperlinks provided by the Internet (Leu et al., 2012 \& Brunmercer, 2019).

Therefore, related to this study, it is vital to recognize the teacher's perception of reading digital texts. It is done to ensure the teacher has the precise concept of reading digital text. 
Besides, teachers need to provide accurate activities to facilitate the students to have new reading literacy in the digital environment (texts). Since explicit teaching and modelling for practices can help students enhance their reading digital comprehension, it will also help students be autonomous learners (Brun-mercer, 2019).

\section{METHOD}

The present study investigates ELT teachers' perception and practices on reading digital text, so a case study is used as the research designed for this study. A case study is qualitative research designed that phenomena/case(s) are explored in detail and in-depth through multiple sources of information (Merriam \& Tisdell, 2016; Yin, 2016)

\section{Respondents}

Twenty-three English teachers from various cities around East Java participated in this study. Eighteen English teachers are from Senior High School, and five teachers are from Junior High School. These teachers have the same situation that they are teachers from suburban schools. When this research is conducted, they are still joining Teacher Professional Development held by the Indonesian Ministry of Education in one private university in Jember.

\section{Instruments}

This study was conducted during Covid - 19 pandemic, so the researcher distributed a questionnaire. An open - ended questionnaire was selected for this study. English teachers- as the subject for this study- were asked to give a short answer for some items using their own words (Heigham \& Croker, 2009). The open - ended questionnaire was contained eight questions; they are including; two questions for teachers' identity, four questions about teachers' experience in practicing reading digital text, one questions about teacher's knowledge, one questions about teachers' attitudes toward the importance of teaching digital reading text as a new reading literacy. The questionnaire will be coded and analyzed to answer how ELT teachers' perceptions of reading digital texts are.

\section{Procedures}

The procedure of this research including; first selection of the participant which was done by sending consent letter to the teachers. Second, researcher distributed the questionnaire to the teachers who willing to joint this study, the questionnaire was sent via Google Form. The 
third stage was analyzing the data gotten from the questionnaire to answer the research questions.

\section{Data analysis}

The data was analyzed through coding manually, including four main steps (Saldana, 2013; Cope, 2016; Elliott, 2018). First, the researcher makes a list of data codes based on the research questions; there are three principal codes; teachers' attitude, teachers' knowledge, and teachers' practice of reading digital text. Second, the researcher analyzes the data collection to relate the data to the listed code in the first step. Third, the researcher was recording or recategorizing the data based on the data found in the analysis. Fourth, the results of the coding data were compared to the theoretical frameworks. The coding data answered the first research question compared to the previous study that claimed the importance of training to read a digital text (Leu et al., 2012). The second research question was answered by comparing the finding with the definition of reading digital text proposed by Leu et al., (2011) \& Leu et al., (2012)) to ensure the teacher has the right concept about reading digital text. Furthermore, to answer the third research question, coding data was compared to the literacy practice of reading digital text proposed by Leu et al. (2012).

\section{FINDINGS AND DISCUSSION}

The result of the data analysis will be displayed according to the research questions. A discussion will follow the data display. This study aimed to investigate English teachers' perception of reading the digital text as a new literacy in reading. The rationale to investigate teachers' perception could depict teachers' attitudes, knowledge, and practices in reading digital text. Investigating teachers' perception of new literacy in online reading (digital text) is crucial since it may affect commitment to engage the students with classroom reading practices that use technology.

\section{Teachers' Attitude Toward Reading Digital Text}

Knowing teachers' attitudes toward the importance of teaching digital reading text is essential since it could describe teachers' internal motivation to provide digital reading text in their English class. All teachers show a positive attitude toward reading the digital text, as is shown in table 1. 
Laeli, Setiawan, Anam, Reading Digital Text...

Table 1. Teacher's attitude on reading digital text

\begin{tabular}{|c|c|}
\hline Teachers' attitude & Verification result \\
\hline $\begin{array}{l}\text { the availability of a broader range of reference or } \\
\text { sources can add insight to students }\end{array}$ & $\begin{array}{l}\text { All teachers have a positive attitude toward teaching } \\
\text { reading digital text in the class }\end{array}$ \\
\hline $\begin{array}{l}\text { Meet the needs of students as the } 21^{\text {st }} \text {-century } \\
\text { generation }\end{array}$ & \\
\hline $\begin{array}{l}\text { Engage students' critical thinking while reading } \\
\text { many sources }\end{array}$ & \\
\hline $\begin{array}{l}\text { students can take advantage of technology as a } \\
\text { medium and learning resource }\end{array}$ & \\
\hline $\begin{array}{l}\text { it increases students' motivation in reading, due to } \\
\text { digital text presents a more attractive visual } \\
\text { appearance than printed text }\end{array}$ & \\
\hline
\end{tabular}

The result revealed that all teachers, both in Junior and Senior High school, perform the same positive attitude toward the practice of reading digital text. Consequently, teachers' attitude represents the personal sense and interpretation as to what to do within and outside the classroom, so that knowing about teachers' attitude is necessary to discover the intimate connection that guides the teachers' decisions for the classroom practices (Laksani, 2019). Besides, the teachers claimed that providing reading digital text could engage the students to think critically since reading digital text allows them to read many sources. This result is confirmed by Brun-mercer (2019) states that the online environment presents opportunities to anyone to publish things rapidly and effortlessly; readers must evaluate information critically. Another positive reason showed by ELT teachers is providing reading digital text to meet the needs of learners in the $21^{\text {st }}$-century. It supports Seok \& DaCosta (2016) that report providing a new learning experience in the classroom is essential to encourage $21^{\text {st }}$-century learners due to technology development and change, particularly in reading. Further, Students in the $21^{\text {st }}$ century need to have an adequate learning experience in reading digital texts; print text instruction does not generally enhance digital texts' output (Brun-mercer, 2019).

\section{Teachers' knowledge of reading digital texts}

Investigating teachers' knowledge of reading digital text is the second focus of this study. To portray it, the English teachers were asked to write the definition of reading digital text. Due to some teachers offer different meanings of reading digital texts, their answers have been classified into a few of the same answers, as shown in Table 2.

Table 2. Teacher's knowledge toward reading digital text 


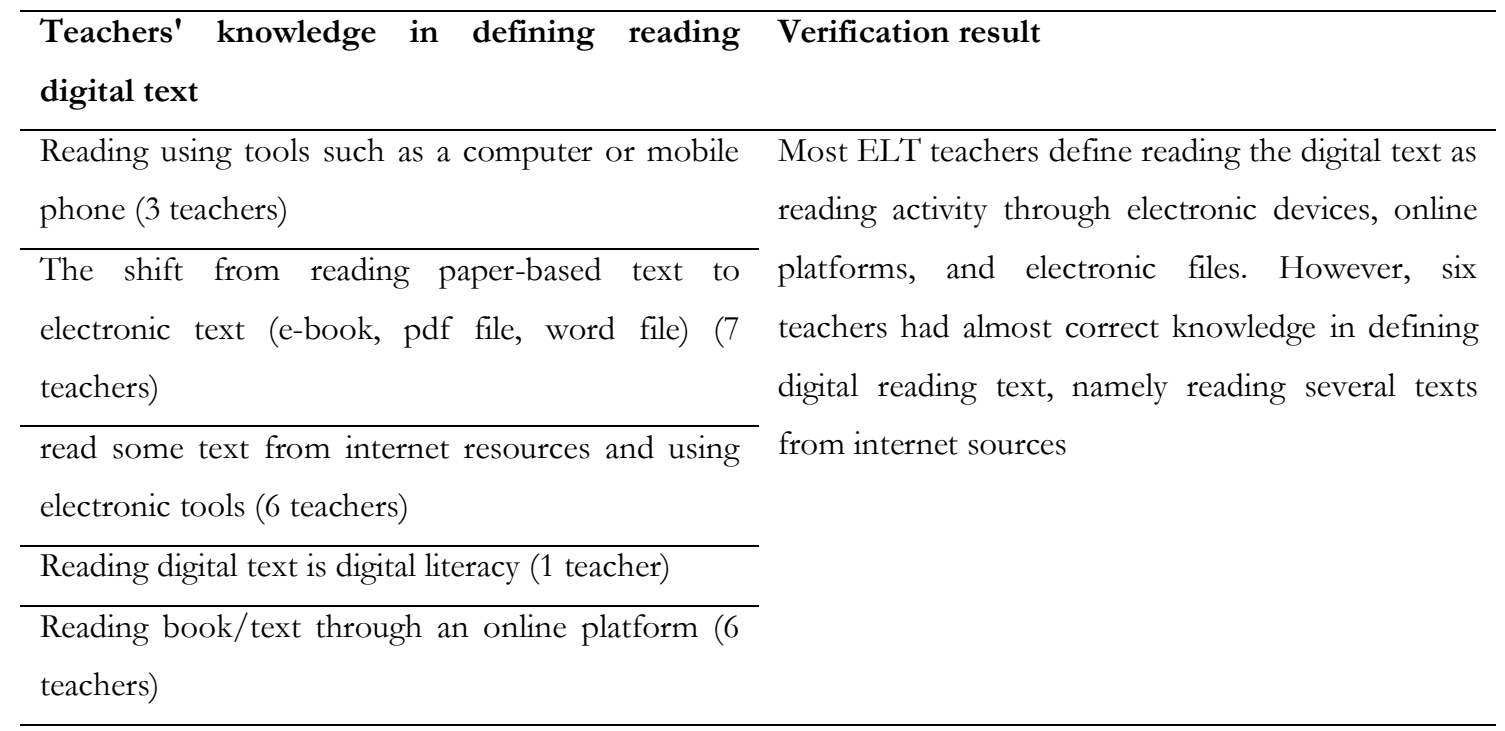

Based on the results show in table 2, there were five different definitions of reading digital texts. The first definition shows that reading digital texts use technological tools such as computers or mobile phones to read. The second definition focuses on changing reading types from printed (hardcopy) to electronic text (softcopy, e.g., e-book, pdf). The third definition explains reading digital text as a reading of various internet sources due to surfing activities in using the internet. The fourth definition shows that reading digital texts is the same definition as digital literacy. Furthermore, the last definition has focused on reading through the digital learning platform (such as Edmodo, Learning management system, Google Classroom). Nevertheless, six teachers out of twenty-three teachers show almost correct definition, which is reading several sources from the internet sources. It is in line with Cho \& Afflerbach (2017) explain that reading digital text refers to read online in the internet sources that allow readers to read the hypertext information, which contains multiple webs, links, and nodes. However, these teachers failed to explain the primary goal of reading digital texts. As it is defined by Leu et al. (2011) that reading a digital text involves a problem-based search process within a large variety of online sources of information through web pages/hyperlinks. Further, it is explained that reading digital text requires reading/searching for information in hypertext or web-based materials that require resource navigation strategies and engaging decision-making to choose appropriate resources (Li, 2020). However, as most of the English teachers in this study define reading digital texts as reading that rely on the technological tools, text type materials, and online learning platforms, it can be concluded that most of the English teachers in this study have a misconception in defining reading digital texts. Yet, referring to one of the previous studies reported that readers who are skilled at using particular features from the internet such as texting, social networking, downloading 
electronics texts, video and MP3 cannot always comprehend the texts in online reading, including evaluating information critically and locating the information (Leu et al., 2012). The result of this current study consistent with a report that explain English teachers need to acknowledge the essence of digital reading to maximize the use of digital texts (Pardede, 2019).

\section{Teachers' practice in implementing reading digital texts activities in the class}

Another crucial issue investigated in this study is the teachers' experience in implementing reading digital text practices. On the questionnaire, teachers were asked if they had ever given online reading activities or instructions related to online reading literacy within the digital texts. The online reading literacy written in the questionnaire was adopted from Leu et al. (2012) \& Brun-mercer (2019). The new reading literacy requires the students to locate, analyze the information, critically evaluate information, and synthesize information from the digital texts.

Table 3. Teacher's practices of reading digital texts

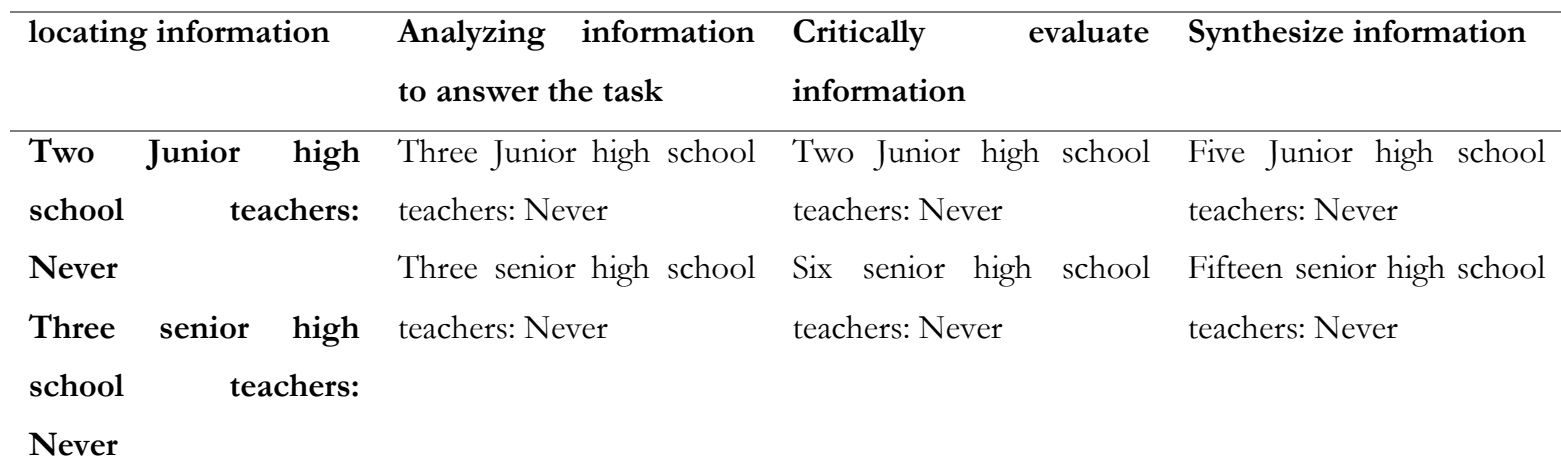

\begin{tabular}{|c|c|c|c|}
\hline $\begin{array}{l}\text { Three Junior high } \\
\text { school teachers: yes }\end{array}$ & $\begin{array}{l}\text { Two Junior high school } \\
\text { teachers: yes }\end{array}$ & $\begin{array}{l}\text { Three Junior high school } \\
\text { teachers: yes }\end{array}$ & $\begin{array}{l}\text { Three senior high school } \\
\text { teachers: yes }\end{array}$ \\
\hline Fourteen senior high & Instruction: & Twelve senior high school & Instruction: \\
\hline \multirow[t]{10}{*}{ school teachers: Yes } & - Find an example & teachers: Yes & - make a paper \\
\hline & of the internet & & about \\
\hline & and analyze the & & importance \\
\hline & generic structure & & English in the \\
\hline & and language & & life of the $21^{\text {st }}$ \\
\hline & features & & century \\
\hline & & & look \\
\hline & Fifteen senior high school & & information \\
\hline & teachers: yes & & various \\
\hline & Instruction: & & sources, books, \\
\hline
\end{tabular}




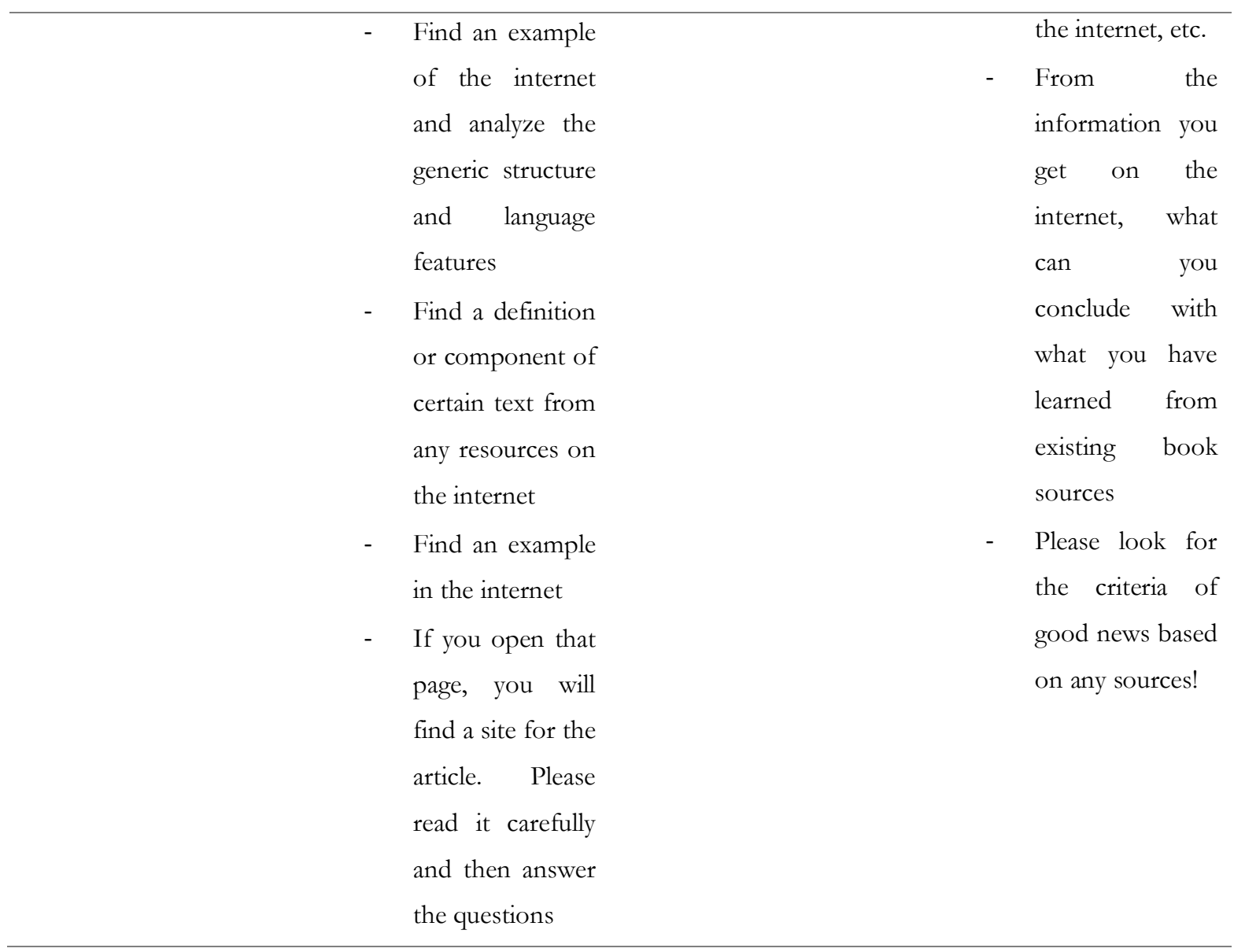

According to the results displayed in table 3, the English teachers reported that among the four online reading literacy, locating information and analyzing information were the most common activities that were assigned to the students in reading online (digital) texts. The following types of literacy that was assigned to the students was to evaluate the information that they got from the internet critically. Furthermore, the last literacy that was rarely assigned to the students was synthesizing the digital texts' information. However, all the English teachers in this study decline to instruct in achieving the online reading literacy goals. As shown in table 3, the example of instructions for analyzing and synthesizing information given to the students was not relevant to online reading literacy's main indicators. As it is explained by Leu et al. (2012), analyzing information refers to the ability to analyzed relevant texts or articles within the hyperlinks, websites, or nodes, and synthesizing information refers to the ability to coordinate the amount of information provided by multiple sources and format (graphic, picture, and others). On the contrary, the teachers' instruction refers to finding an answer from the internet and analyzing the generic structure of the text; it is not required for the students to analyze the information's content. The same instruction for synthesizing information does not show that the students should read multiple texts to synthesize it. 
Regrettably, this study simply did not ask the teacher to write examples of instruction for the literacy of locating and critically evaluate information. Future researches need to address the example of instruction for these two types of literacy in online reading. According to Leu et al. (2012), locating information assigns the ability to generate efficient and effective keyword search techniques for reading and inferring which websites or links can be most relevant in the search engine results. Furthermore, critically evaluate information indicates the ability to read and assess the information's reliability, accuracy, and subjectivity. It is indeed a matter that the most incredible difficulty in digital text reading is navigating the hypertext to find relevant information (Hahnel et al., 2016). This navigation illustrates how the readers access the information part of the task-completion pages. Definitely, students must read complex texts, understand and compare the contents of various texts, and understand them well in a hypertext environment (Cho \& Afflerbach, 2017).

Teachers' misperceptions and practices, as mentioned above, happen due to several possibilities; they are English teachers who do not have the experience to expose online reading literacy. Another possible factor is that teachers did not update their technological pedagogical content knowledge (TPACK), particularly in online reading, to meet today's students' needs. As the English teachers admitted in the online questionnaire (figure 3), almost all English teachers (twenty - two) never receive a particular workshop on teaching reading a digital text as the implication of online reading in the class. Only one person claimed to receive the workshop, but the researchers did not conduct further investigations on the teacher who claimed to have received training to confirm whether the training had focused on online reading literacy practices.
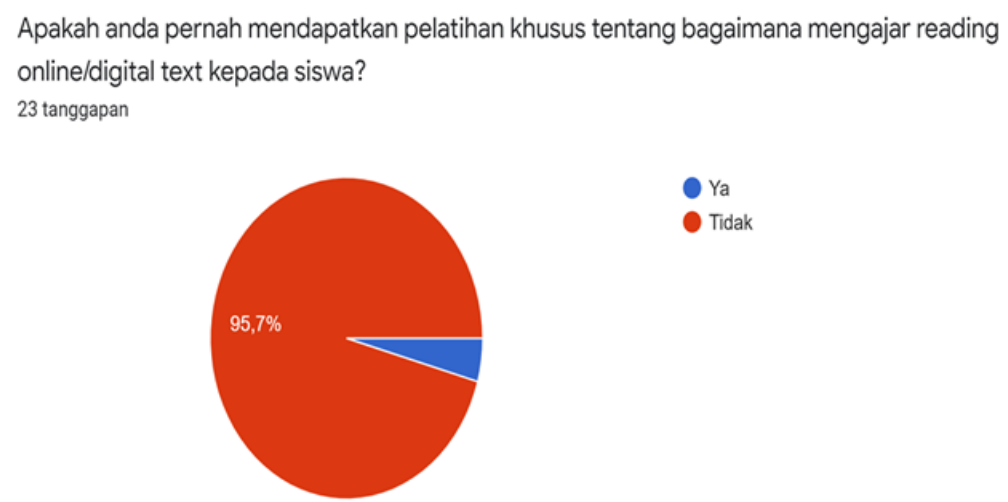

Figure 1. teachers' report about the workshop on teaching online reading

This finding supports the result of a previous study that confirms it is essential to provide regular workshops on the development of technology for English teaching (Laksani, 2019). 
Regular workshops on technology for English teaching will help teachers have sufficient knowledge and experience in successfully utilizing technology in the classroom, particularly reading online within digital texts. For, the strategy process typically begins with teacher training in an attempt for learners to know both how to execute the strategy and why it is beneficial (Brun-mercer, 2019). Then, instructors often decline to integrate technology into the reading class due to limited resources, knowledge, or training (Dobler \& Eagleton, 2015). Teachers' knowledge, attitude, and experience affect how teachers provide reading practices, particularly in digital text. Therefore, the teacher needs more practice in reading digital text to help the students in the class, that is by attending a regular workshop on teaching reading digital text.

\section{E. CONCLUSION}

As a result of this study, teachers show a positive attitude toward reading digital text, but they have misconceptions about knowledge and practice. So, it is suggested that English teachers need to be provided specific knowledge of reading online as the new literacy. Furthermore, as the policymaker for teacher professional development, the Indonesian Ministry of Education and Culture should provide a systematic workshop for ELT teachers to read the digital text as the implication of reading online through the internet in the ELT classroom. However, this study is limited to the teacher's perception and practices of reading digital text in the ELT class. It did not consider the teacher's digital literacy competence and reading digital text comprehension. Future researchers need to investigate ELT teachers' digital literacy and read digital text competence and its implication on how teachers provide reading digital text practices. This current study contributes to sequence implications to enhance teachers' digital literacy practices, particularly in teaching reading for digital text (online). Finally, it is hoped that this study will give a substantial contribution to new digital literacy for ELT teachers, particularly in reading digital text.

\section{REFERENCES}

Brun-mercer, N. (2019). Online Reading Strategies for the Classroom. English Teaching Forum, 2-11.

Cho, B.-Y., \& Afflerbach, P. (2017). An Evolving Perspective of Constructively Responsive Reading Comprehension Strategies in Multilayered Digital Text Environments. In E. Susan (Ed.), Handbook of Research on Reading Comprehension (Issue January, pp. 1-28). Guilford Publications. 
Coiro, J., \& Dobler, E. (2007). Exploring the online reading comprehension strategies used by sixth-grade skilled readers to search for and locate information on the Internet. Reading Research Quarterly, 42(2), 214-257. https://doi.org/10.1598/rrq.42.2.2

Conrad, D., \& Pedro, J. (2009). Perspectives on Online Teaching and Learning : A Report of Two Novice OnlineEducators Perspectives on Online Teaching and Learning: A Report of Two Novice. International Journal for the Scholarship of Teaching and Learning (IjSOTL), 3(2), 1-17.

Cope, M. (2016). Part III ' Interpreting and Communicating' Qualitative. Coding Qualitative Data, February.

Dobler, E., \& Eagleton, M. B. (2015). Reading the web: Strategies for internet inquiry. (second Edi). Guilford Publications.

Elliott, V. (2018). Thinking about the Coding Process in Qualitative Data Analysis. The Qualitative Report, 23(11), 2850-2861.

Gilbert, J. (2017). A Study of ESL Students' Perceptions of Their Digital Reading. An International Journal Online, 17(2), 179-195.

Hahnel, C., Goldhammer, F., Naumann, J., \& Kröhne, U. (2016). Effects of linear reading, basic computer skills, evaluating online information, and navigation on reading digital text. Computers in Human Behavior, 55, 486-500. https://doi.org/10.1016/j.chb.2015.09.042

Harris, K. (2015). Integrating digital literacy into English language instruction: Issue brief. Literacy Information and Communication System, 1-9. https://lincs.ed.gov/sites/default/files/ELL_Digital_Literacy_508.pdf

Heigham, J., \& Croker, R. A. (2009). Qualitative Research in Applied Linguistics; A Practical Introduction. Palgrave Macmillan.

Laksani, H. (2019). Teacher's Belief about Digital Literacy Based on Theory of Planned Behavior. Teaching and Learning English in Multicultural Contexts (TLEMC), 3(2), 63-73. http://jurnal.unsil.ac.id/index.php/tlemc/article/view/1269

Leu, D. J., Everett-Cacopardo, H., Zawilinski, L., Mcverry, J. G., \& O ’byrne, A. W. I. (2012). 
New Literacies of Online Reading Comprehension. The Encyclopedia Of Applied LInguistics, 1-9. https://doi.org/10.1002/9781405198431.wbeal0865

Leu, D. J., McVerry, J. G., O’Byrne, W. I., Kiili, C., Zawilinski, L., Everett-Cacopardo, H., Kennedy, C., \& Forzani, E. (2011). The New Literacies of Online Reading Comprehension: Expanding the Literacy and Learning Curriculum. Journal of Adolescent \& Adult Literacy, 53(September), 5-14. https://doi.org/10.1598/JA

Li, J. (2020). Development and validation of Second Language Online Reading Strategies Inventory. Computers and Education, 145, 103733. https://doi.org/10.1016/j.compedu.2019.103733

Merriam, S. B., \& Tisdell, E. J. (2016). Qualitative Research A Guide to Design and Implementatiob (Fourth). Jossey-Bass.

Murtafi'ah, B., \& Putro, N. H. P. S. (2019). DIGITAL LITERACY IN THE ENGLISH CURRICULUM: MODELS OF LEARNING ACTIVITIES. Acta Informatica Malaysia, 3(2), 11-14.

Ozden, M. (2018). Digital Literacy Perceptions of the Students in the Department of Computer Technologies Teaching and Turkish Language Teaching Digital Literacy Perceptions of the Students in the Department of Computer Technologies Teaching and Turkish Language Teaching. International Journal of Progressive Education, 14(4). https://doi.org/10.29329/ijpe.2018.154.3

Pardede, P. (2019). Print vs Digital Reading Comprehension in EFL. Journal of English Teaching, 5(2), 77-90. https://doi.org/10.33541/jet.v5i2.1059

Park, H. R., \& Kim, D. (2017). English language learners' strategies for reading online texts: Influential factors and patterns of use at home and in school. International Journal of Educational Research, 82(October), 63-74. https://doi.org/10.1016/j.ijer.2017.01.002

Pratolo, B. W., \& Solikhati, H. A. (2020). The implementation of digital literacy in indonesian suburban EFL classes. International Journal of Scientific and Technology Research, 9(1), $1508-1512$.

Prensky, M. (2001). Digital Natives, Digital Immigrants. On the Horizon, 9(5), 3961-3979. 
Laeli, Setiawan, Anam, Reading Digital Text...

https://doi.org/10.1177/1461444818783102

Saldana, J. (2013). The Coding Manual for Qualitative Reseachers (Second Edi). British Library Cataloguing.

Seok, S., \& DaCosta, B. (2016). Perceptions and preferences of digital and printed text and their role in predicting digital literacy. Asian Social Science, 12(5), 14-23. https://doi.org/10.5539/ass.v12n5p14

Trilling, B., \& Fadel, C. (2009). 21st Century Skills: Learninh for Life in Our Times. John Wiley \& sons, Inc.

Wiraningsih, P., \& Santosa, M. H. (2020). EFL teachers' challenges in promoting learner autonomy in the 21st - century learning. Journal on English as a Foreign Language, 10(2), 290-314.

Yin, K. R. (2016). Qualitative Research from Start to Finish (Second). The Guilford Press. 